\title{
CUSTODIAL LEGAL ASSISTANCE AND NOTIFICATION OF THE RIGHT TO SILENCE IN FRANCE: LEGAL COSMOPOLITANISM AND LOCAL RESISTANCE
}

\author{
DIMITRIOS GIANNOULOPOULOS*
}

\begin{abstract}
Until enactment of the Law of 14 April 2011, suspects questioned by the police in France were entitled to meet their lawyer only once in the first 24 hours of custodial interrogation and only for thirty minutes, and were not notified of their right to silence. Extrapolating from French criminal procedure's pre-April $14^{\text {th }}$ exceptionalism in this area, this article challenges the position of modern legal systems' fast growing cosmopolitanism and argues that when one moves from rough generalisations to specific contextual inquiries, a more nuanced picture of legal systems' cosmopolitan tendencies may emerge. But this article also demonstrates that legal cosmopolitanism can be a powerful force for legal reform. The April $14^{\text {th }}$ legislation was introduced quickly as a result of European Court of Human Rights jurisprudence against the backdrop of two centuries' incremental development of French criminal procedure in this domain. This contrast lends itself to translating the April $14^{\text {th }}$ reforms as a result of cosmopolitan pressures coming from outside the national legal system rather than cosmopolitan attitudes spontaneously generated from within. The article illustrates that external cosmopolitan pressures go hand in hand with local resistance, that legal nationalism underpins local resistance and that resistance fluctuates depending on the institution at the receiving end of cosmopolitan pressures. It concludes that indigenous cosmopolitan attitudes, generated through a renewed emphasis on comparative law, can better accommodate resistance.
\end{abstract}

Keywords: reform of criminal law, foreign and comparative law, police interrogation, suspects' rights, ECHR, legal cosmopolitanism.

\section{INTRODUCTION}

The decision of the European Court of Human Rights (ECtHR) in Salduz v Turkey ${ }^{1}$ has led to considerable reforms of custodial interrogation regimes in many European countries. $^{2}$ In France, it paved the way for the introduction of legislation - the Law of

\footnotetext{
${ }^{*}$ Lecturer, Brunel Law School, Brunel University, London. Docteur en droit (Ph.D), University of Paris I (Panthéon-Sorbonne). I am most grateful to Professors Michael Bohlander, Andrew Choo, Jacqueline Hodgson, Abimbola Olowofoyeku, Paul Roberts and John Spencer, and to Aurélie BinetGrosclaude, for their comments on written versions. An earlier draft has benefited from presentation at the W.G. Hart Legal Workshop on 'Globalisation, Criminal Law and Criminal Justice' (IALS and Queen Mary University, London, June 26-28, 2012).

${ }^{1}$ (2008) EHRR 421.

2 This decision has unsettled custodial interrogation practice in Belgium and the Netherlands (see text to $\mathrm{n}$ 61-64). In the UK, a number of high-profile Supreme Court cases applying Salduz have had a major impact on the regime of custodial interrogation in Scotland. See Cadder v. HM Advocate [2010]
} 
14 April $2011^{3}$ relating to the garde à vue $e^{4}$ which recognized for the first time the right of suspects to have their lawyer present when questioned by the police. ${ }^{5}$ Until then, suspects were entitled to meet with a lawyer only once during the first 24 hours of the garde $\grave{a}$ vue and only for thirty minutes. ${ }^{6}$ This legislation also reintroduced the duty for the police to notify suspects of their right to remain silent, ${ }^{7}$ which had had a short and troubled history until then. ${ }^{8}$ These developments set in motion a transition from a model of custodial interrogation rooted in the inquisitorial tradition to a model more consistent with adversarial principles.

I understand an inquisitorial model of custodial interrogation as one that is mainly characterized by limited access to legal advice, lawyers' passive role and reduced opportunity to contradict the officials in charge of the process, and even an expectation for the defence to assist in the discovery of truth. ${ }^{9}$ I see this as opposed to an adversarial orientated model, which places emphasis on legal assistance and the ability to contest the officials, while being averse to compelling the suspect to convert into an informational source. ${ }^{10}$ The right to legal assistance and the notification of the right to silence mirror these adversarial goals. ${ }^{11}$ The injection of these two rights into

UKSC 43; [2010] 1 WLR 2601. See also Ambrose v. Harris [2011] UKSC 43; [2011] 1 WLR 2435; HM Advocate v. P [2011] UKSC 44; [2011] 1 WLR 2497; McGowan v. B [2011] UKSC 54; Jude v. HM Advocate [2011] UKSC 55; P. Ferguson, 'Repercussions of the Cadder Case: the ECHR's Fair Trial Provisions and Scottish Criminal Procedure' [2011] Criminal Law Review 743; R. White and P. Ferguson, 'Sins of the Father? The "Sons of Cadder" , [2012] Criminal Law Review 357.

${ }^{3}$ Loi n $^{\circ}$ 2011-392 du 14 avril 2011 relative à la garde à vue.

${ }^{4}$ The garde à vue can be translated as a coercive measure allowing for the detention and questioning of suspected offenders by the police. See art 62-2 CPP (Code de procédure pénale; Code of criminal procedure).

${ }^{5}$ Art 63-4-2 CPP, created by the Law of 14 April 2011.

${ }^{6}$ Art 63-4 CPP, prior to modifications with the Law of 14 April 2011.

${ }^{7}$ Art 63-1 CPP, modified by the Law of 14 April 2011. Other notable amendments of the Law of 14 April 2011 were the recognition of a right for lawyers to access certain documents (art 63-4-1 CPP) and a right for suspects to inform their employer of the garde à vue (art 63-1 CPP).

${ }^{8}$ Note, however, that in interrogations undertaken by the investigating judge (juge d'instruction), the suspect must be notified of his right to silence and has the right to legal assistance. See art 116 CPP.

${ }^{9}$ See generally M. Damaška, The Faces of Justice and State Authority: A Comparative Approach to the Legal Process (Yale: Yale University Press, 1986) 164. See also J. Bell, French Legal Cultures (London: Butterworths, 2001) 150; S. Field and A. West, 'Dialogue and the Inquisitorial Tradition: French Defence Lawyers in the Pre-Trial Criminal Process' [2003] Criminal Law Forum 261, 285; C. Slobogin, 'An Empirically Based Comparison of American and European Regulatory Approaches to Police Investigation' in P.J. Van Koppen and S.D. Penrod, Adversarial versus Inquisitorial Justice Psychological Perspectives on Criminal Justice Systems (New York: Kluwer Academic/ Plenum Publishers, 2003) 27, 45; P. Duff, 'Changing Conceptions of the Scottish Criminal Trial: The Duty to Agree Uncontroversial Evidence' in A. Duff and others (eds), The Trial on Trial - Volume One: Truth and Due Process (Oxford: Hart Publishing, 2004) 29, 30; J. Cédras, La justice pénale aux Etats-Unis $\left(2^{\text {nd }}\right.$ edn, Paris: Economica, 2005) 5; J. Hodgson, French Criminal Justice: A Comparative Account of the Investigation and Prosecution of Crime in France (Oxford: Hart Publishing, 2005) 26.

${ }^{10}$ See Moran v. Burbine 475 US 412, 434-435 (1986) [Stevens J, dissenting, quoting Watts v. Indiana 338 US 49, 54 (1949)]. Damaška, ibid. 126; E. Grande, 'Dances of Criminal Justice: Thoughts on Systemic Differences and the Search for Truth' in J. Jackson, M. Langer and P. Tillers (eds), Crime, Procedure and Evidence in a Comparative and International Context: Essays in Honour of Professor Mirjan Damaška (Oxford: Hart Publishing, 2008) 145; D. A. Sklansky, ‘Anti-Inquisitorialism', 122 Harvard Law Review 1635, 1665 (2009); J. Hodgson, 'The Future of Adversarial Criminal Justice in $21^{\text {st }}$ Century Britain', 32 North Carolina Journal of International Law \& Commercial Regulation 319, 331 (2010).

${ }^{11}$ The recognition of the right to silence in modern criminal procedure is inextricably linked to the historic transition from the inquisitorial to the adversarial model, and the emergence of the suspect as a subject of the criminal process. T. Dalakouras, 'The Suspect's Silence in the Criminal Process' (1989) 43 Armenopoulos 317 (in Greek). See also J. McEwan, Evidence and the Adversarial Process $\left(2^{\text {nd }}\right.$ edn, 
an inquisitorial phase of the criminal process in France provides the background against which the two notions central to this article - legal cosmopolitanism and local resistance - will be investigated.

The concept of legal cosmopolitanism is flexible and elusive. ${ }^{12}$ For the purposes of the inquiries that follow, it will be perceived as a modern phenomenon that is 'exemplified by the conjunction of an increasingly robust international human rights law ... with the rapid evolution of transnational criminal justice policy making', ${ }^{13}$ the unprecedented proliferation of international criminal courts and the emergence of a dialogue between supreme court judges and other leading members of the legal community in different legal systems. ${ }^{14}$ Now attesting to such a cosmopolitan character of modern legal systems is rapidly becoming cliché. National law is seen as interacting with foreign law more frequently than ever before ${ }^{15}$ and as being shaped under international and transnational law influences that are so dynamic as to call into question the 'capacities, competencies and legitimation claims of the nation state itself', ${ }^{16}$ to the extent that 'justice can no longer be seen as a purely local phenomenon'. ${ }^{17}$ Traditions and legal orders are observed as opening to each other, living in each other's midst, in ways that allegedly strongly resonate with the cosmopolitan vision of Kant and Derrida. ${ }^{18}$ 'Law is thus [conceived as being] open to the world', 19 making redundant 'a static conception of laws in favor of a vision decidedly evolutionary'. ${ }^{20} \mathrm{We}$ are even beginning to look for signs of emerging unified legal cultures, for example 'a European legal culture, distinct from preexisting national traditions', ${ }^{21}$ and we have already envisioned the creation of a 'global legal culture'. ${ }^{22}$ The question then arises on how, in a time of cosmopolitan law, phenomena unveiling the isolationism and exceptionalism of a particular legal system ought to be interpreted.

Oxford: Hart Publishing, 1998) 168. This is a fortiori the case with respect to recognition of the right to legal assistance. See generally G.A. Magkakis, The Lawyer: A Paradoxical Conquest of Civilization Study Not Just for Jurists (Athens: A.N. Sakkoulas, 2004) 33 (in Greek).

${ }^{12}$ P. Roberts, 'Rethinking the Law of Evidence: a Twenty-First Century Agenda for Teaching and Research' in P. Roberts and M. Redmayne (eds), Innovations in Evidence and Proof: Integrating Theory, Research and Proof (Oxford: Hart Publishing, 2007) 19, 50.

${ }^{13}$ P. Roberts, 'Faces of Justice Adrift? Damaška's Comparative Method and the Future of Common Law Evidence' in Jackson, Langer and Tillers (eds) (n 10 above) 295, 325.

${ }^{14}$ J. Bell, Book Review (2003) 52 ICLQ 270.

${ }^{15}$ C. Rozakis, 'The European Judge as a Comparatist', 80 Tulane Law Review 257, 258 (2005-2006).

${ }^{16}$ A. Crawford (ed), International and Comparative Criminal Justice and Urban Governance: Convergence and Divergence in Global, National and Local Settings (Cambridge: Cambridge University Press, 2011) 1. See also J. McLean, 'From Empire to Globalization: The New Zealand Experience', 11 Indiana Journal of Global Legal Studies 161 (2004); J. Habermas, The Divided West (Cambridge: Polity, 2006) 176; D. Held, Cosmopolitanism: Ideals and Realities (Cambridge: Polity, 2010) Chapter 3.

${ }^{17}$ R. Vogler, A World View of Criminal Justice (Aldershot: Ashgate, 2005) 2.

${ }^{18}$ R. Janda, 'Toward Cosmopolitan Law', 50 McGill LJ 967, 981 (2005).

${ }^{19}$ G. Canivet, 'The Practice of Comparative Law by the Supreme Courts: Brief Reflections on the Dialogue Between the Judges in French and European Experience' in B. Markesinis and J. Fedtke (eds), Judicial Recourse to Foreign Law: A New Source of Inspiration (London: UCL Press, 2006) $308,312$.

${ }^{20}$ Ibid.

${ }^{21}$ H. Muir Watt, 'Evidence of an Emergent European Legal Culture: Public Policy Requirements of Procedural Fairness Under the Brussels and Lugano Conventions', 36 Texas International Law Journal 539, 541 (2001).

${ }^{22}$ R. Menyhart, 'Changing Identities and Changing Law: Possibilities for a Global Legal Culture', 10 Indian Journal of Global Legal Studies 157 (2003). 
The starting point for this line of inquiry will be the observation that until the April 2011 reform suspects in France were deprived of two of the most commonly cited procedural rights applying to custodial interrogation - legal assistance and notification of the right to silence -, in stark contrast to foreign and international law. This insular approach sits uneasily with a view of the French legal system as cosmopolitan. A cosmopolitan legal system is arguably characterized by 'breadth of vision' and 'freedom from parochial limitations and attachments', ${ }^{23}$ as evidenced, in particular, by its willingness and capacity to interact with foreign and international law, 'to open a dialogue with laws and legal practices developed outside [its] jurisdictional confines in [an] effort to draw inspiration from them' ${ }^{24}$ Conversely, a legal system where national solutions are disconnected from those presented by foreign and international law, and which 'closes itself off in a particularistic fashion', to borrow a phrase from Habermas, ${ }^{25}$ cannot make a valid claim to having a cosmopolitan vision. From this angle, the observation about pre-April $14^{\text {th }}$ isolationism lends itself to the interpretation that when one moves from rough generalizations to specific contextual inquiries, a more nuanced picture of modern legal systems' cosmopolitan tendencies may emerge, hence the need for contextual inquiries that can shed light on the complex relationship between the cosmopolitan attitudes inherent in international and comparative law's growing influence and the provincial attitudes that the same external influences may generate.

At the same time, with the Law of April $14^{\text {th }}$, the transition from an out-ofsync position to a sudden realignment with the international community is of particular value when extrapolating French criminal procedure's cosmopolitan character, or lack thereof, from its approach to the two rights examined here. This is particularly so given the unquestionable impact of the European Convention on Human Rights (ECHR) on this transitional process, which can be deciphered as a clear sign of cosmopolitan tendencies manifesting themselves. It is equally intriguing to observe how the impact of external cosmopolitan influences fluctuates depending on the institution that is at the receiving end. The judiciary has been quick to translate these external influences into a true driving force for reform. The executive and the legislature have received the same influences with much less enthusiasm, which resulted in often undercurrent yet strongly felt forces of local resistance distorting the adversarial vision of the reform.

This sharp contrast between legal cosmopolitanism and local resistance, as opposite forces shaping law reform, will form the backbone of my argument. Put another way, my inquiries will be situated within the context of two conflicting trends, insightfully described by the former First President of the Cour de cassation (Supreme Court of France), Guy Canivet: 'the incommensurability - irreducibility of legal cultures, on the one hand, and convergence, on the other, [which] set in motion contradictory movements between singularity and rapprochement in the legal systems'. ${ }^{26}$ Section II will highlight France's exceptionalism in regulating custodial interrogation. Section III will present an opportunity to contrast this insular approach with the almost reflexive response to ECtHR jurisprudence. Finally, Section IV will identify important signs of local resistance to cosmopolitan pressures to move in a

\footnotetext{
${ }^{23}$ W. Twining, 'Cosmopolitan Legal Studies' (2002) 9 International Journal of the Legal Profession 99, 103.

${ }^{24}$ Rozakis (n 15 above) 257.

25 J. Habermas, Between Facts and Norms: Contributions to a Discourse Theory of Law and Democracy (Cambridge: Polity, 1996) 514.

${ }^{26}$ Above (n 19) 310.
} 
more adversarial direction. In this way, it will be argued that, despite appearances to the contrary, we might still be a long way from witnessing the emergence of cosmopolitan legal systems that spontaneously engage in constructive dialogue with foreign legal cultures and international law.

\section{FRENCH EXCEPTIONALISM}

Lawyers can historically be regarded as personae non gratae at police stations in France, and the right to silence is an illusion. The historical review that follows will provide evidence for this. ${ }^{27}$ Examples from foreign and international law will support a diagnosis of considerable pre-April $14^{\text {th }}$ exceptionalism in this area.

\subsection{Custodial Legal Assistance and Notification of the Right to Silence Prior to the Law of 14 April 2011}

Suspects in France first obtained the right to consult a lawyer during the garde à vue with the Law of 4 January $1993 .{ }^{28}$ Introduced by a Socialist government, this legislation gave suspects the right to request a meeting with a lawyer, lasting a maximum of thirty minutes, from the beginning of the garde à vue. ${ }^{29}$ This consisted in a small revolution, according to no less an authority than the Minister of Justice at the time. ${ }^{30}$ However, despite breaking with the past, it is hard to see how the embryonic right, which had inherited the inquisitorial legacy of non-interference with the power of the police to conduct interrogations, could be conceived as anything more than a reserved move towards recognizing a limited role for lawyers in custodial interrogation. In any case, the Commission Justice pénale et droits de l'homme had proposed a much more progressive solution. Chaired by the eminent comparatist Mireille Delmas-Marty, the Commission looked into custodial interrogation legislation in a number of common law and civil law countries, ${ }^{31}$ and examined relevant norms of international law, ${ }^{32}$ before proposing that the suspect should have

\footnotetext{
${ }^{27}$ This brief overview of reforms relating to custodial legal assistance and notification of the right to silence can be read with Jacqueline Hodgson's more analytical accounts of the reforms of the garde à vue that have taken place since the beginning of the 90s and, especially, between 1993 and 2004. See, in particular, 'Constructing the Pre-trial Role of the Defence in French Criminal Procedure: an Adversarial Outsider in an Inquisitorial Process' (2002) 6 E \& P 1; 'Codified Criminal Procedure and Human Rights: Some Observations on the French Experience' [2003] Crim LR 165, 173; French Criminal Justice (n 9 above) 39. See also Field and West, 'Dialogue and the Inquisitorial Tradition' (n 9 above) 284; R. Vogler, 'Reform Trends in Criminal Justice: Spain, France and England \& Wales', 4 Washington University Global Studies Law Review 631, 634 (2005).

${ }^{28}$ The Napoleonic Code d'instruction criminelle 1808 was providing for the right to be assisted by a lawyer solely at trial, while the Law of 8 December 1897 had extended the right to the pre-trial phase, but only in relation to interrogations undertaken by the investigating judge. In fact, custodial interrogation remained a 'legal black hole' until the Code of Penal Procedure 1959 regulated the practice, but there was again no provision for legal assistance. See J. Pradel, 'Vers une métamorphose de la garde à vue. Après la "décision pilote" du Conseil constitutionnel du 30 juillet 2010 et les arrêts de la chambre criminelle du 19 septembre 2010', Recueil Dalloz 2010, 2783; J. Pradel, 'Centenaire de la loi du 8 décembre 1897 sur la défense avant jugement pénal: essai d'un bilan', Recueil Dalloz 1997, 375.

${ }^{29}$ Art 63-4 CPP.

${ }^{30}$ Débats Assemblée nationale, 30 November 1992, 6272.

${ }^{31}$ La mise en état des affaires pénales (Paris: La documentation française, 1991) 38. The Commission took its comparative law examples from the United States, the United Kingdom, Canada, Italy, Portugal and West Germany.

${ }^{32}$ Ibid., at 83 .
} 
the right to be continuously assisted by a lawyer during questioning, and that the lawyer should be able to ask questions and permanently access the investigation dossier. ${ }^{33}$

However, consultation at the beginning of the garde à vue was already seen as going too far in an adversarial direction. Thus, when a government of the Right came into power, only three months after this legislation was enacted, it voted the Law of 24 August $1993^{34}$, which moved the first meeting with a lawyer to 20 hours into the garde $\grave{a} v u e^{35}$ and created exceptional regimes of garde à vue, barring suspects' access to a lawyer for 36 hours in cases of organized crime and 72 hours in cases relating more specifically to terrorism and drug-related offences. ${ }^{36}$

The political ping-pong did not end there. A Socialist government introduced the loi sur la présomption d'innocence ('Law of the presumption of innocence') in June 2000. ${ }^{37}$ This reform was orientated towards protecting suspects' rights; recognizing the right to meet with a lawyer from the outset of the garde à vue was an important pillar in the effort to achieve this. ${ }^{38}$ More precisely, the new regime provided for thirty-minute meetings at the beginning of the garde à vue and then 20 hours into the process, as well as 36 hours after the beginning of the garde à vue, in cases where the latter would be extended beyond the 24-hour time limit. Outside these short periods of time, however, lawyers would not be allowed to meet their client. They would have no access to the investigation dossier either, even though they would be informed of the presumed date and nature of the suspected offence. From this point of view, it is hard to imagine how one would disagree with the view that the lawyer's intervention in the garde à vue was of limited legal significance under this legislation, consisting in nothing more than an opportunity to offer psychological support, 'reassure the interested party by explaining to him what, eventually, awaits him'. ${ }^{39}$ The 2000 legislation also maintained the exceptional regimes of garde à vue, which is further proof of the quite mitigated effect it has had upon the inquisitorial character of the latter. Nevertheless, this legislation was met with great scepticism, mainly on the part of the police, but in some academic circles as well. ${ }^{40}$

\footnotetext{
33 Ibid., at 113. In Continental legal systems, documents relating to police investigation and interrogation are typically concentrated on an 'investigation dossier' that is freely accessible by the parties throughout the pre-trial stage of the criminal process.

${ }^{34}$ Loi $n^{\circ} 93-1013$ du 24 août 1993 modifiant la loi $n^{\circ} 93-2$ du 4 janvier 1993 portant réforme de la procédure pénale.

${ }^{35}$ Art 63-4 CPP modified by the Law of 24 August 1993.

${ }^{36}$ Art 63-4 CPP. The circular of the August legislation characteristically explained that 'the efficiency of the repressive apparatus' had to be guaranteed. See JORF n 196 du 25 août 1993, Circulaire du 24 août 1993 relative à la loi n 93-1013 modifiant la loi nº 93-2 du 4 janvier 1993 portant réforme de la procédure pénale.

${ }^{37}$ Loi $\mathrm{n}^{\circ} 2000-516$ du 15 juin 2000 renforçant la protection de la présomption d'innocence et les droits des victimes.

${ }^{38}$ F. Taquet, 'Brèves approches sur les nouvelles dispositions relatives à la garde à vue', La Gazzette du Palais, 8-9 septembre 2000, 9, 10.

${ }^{39}$ T. Garré, 'Les droits de la défense en procédure pénale' in R. Cabrillac, M. A. Frison-Roche and T. Revet, Libertés et droits fondamentaux (11 ${ }^{\text {th }}$ edn, Paris: Dalloz, 2005) 513, 520.

${ }^{40}$ Pradel's comments are symptomatic of such scepticism. His concern was that application of the right would impact on the efficiency of the criminal process and that lawyers would lobby for the right to assist permanently their clients during questioning. See J. Pradel, 'Encore une tornade sur notre procédure pénale avec la loi du 15 juin 2000', Recueil Dalloz 2000, point de vue, 5, 6 ; J. Pradel, 'Les personnes suspectes ou poursuivies après la loi du 15 juin 2000: évolution ou révolution?', Recueil Dalloz 2001, chr, 1042.
} 
Despite all this, the 2000 legislation represented, until the April 2011 reforms at least, the 'high point in the legislation of due process protections'. ${ }^{41}$ Supposing that this was indeed the liberal era of criminal procedure reforms, 9/11 and its aftermath marked its end. With respect to custodial legal assistance, legislation introduced in 2004 now allowed for a second meeting between the suspect and his lawyer only at the beginning of the extension of a garde à vue beyond the 24-hour time limit. ${ }^{42}$ This meant that there would be no opportunity for a second meeting in cases where the interrogation would be terminated before the expiry of that limit. Furthermore, in relation to organized crime offences, the time of the first meeting was moved to 48 hours into the garde à vue, with a second meeting 72 hours into it, while in relation to terrorist and drug-related offences, the suspect would have no access to counsel before a whole 72 hours had passed. ${ }^{43}$ The 2004 legislation constituted an important axis in France's fight against terrorism after 9/11. The changes it brought to access to legal advice must therefore be seen through the prism of the securitarian obsession that characterized France in that period. ${ }^{44}$

We have seen that since the beginning of the 1990s much ink has been spilt over the exact moment in which the lawyer should intervene in the garde à vue, and yet, until the Law of 14 April 2011, progress in this area had been marginal. 'One step forward, two steps back' epitomizes the effect of successive legal reforms. The same can be said of developments concerning notification of the right to silence. First of all, it was only in 2000 that a caution was enacted into positive law; for the first time police officers had to inform a suspect, immediately upon detention, that he had 'the right not to respond to the questions that [would] be posed to him by the investigators'. ${ }^{45}$ In the eyes of an academic commentator, this was 'a highly symbolic move'. ${ }^{46}$ The right had previously only been based on the jurisprudence of the ECtHR,${ }^{47}$ but it was now being incorporated into the Code of Penal Procedure. ${ }^{48}$ At the same time, there were strong reservations about this reform. They were first mirrored in a Ministry of Justice circular, ${ }^{49}$ which explained that the right should not be 'understood as enabling the suspect to put an end to his interrogation' and that 'a first refusal to speak [would] evidently not prohibit investigators from continuing to ask all the questions that might appear necessary to them, ${ }^{50}$ Reservations turned into uneasiness first, dislike later, as the pendulum swung from the liberty- and rightscentred debates that were central to the 2000 legislation to a post-9/11 environment

\footnotetext{
${ }^{41}$ Hodgson, French Criminal Justice (n 9 above) 45.

${ }^{42}$ Art 63-4 s. 6 CPP, modified by the Law of 9 March 2004 (Loi n 2004-204 du 9 mars 2004 portant adaptation de la justice aux évolutions de la criminalité).

${ }^{43}$ Art 63-4 s. 7 CPP, modified by the Law of 9 March 2004.

${ }^{44}$ See L. Mucchielli (éd), La frénesie sécuritaire: retour à l'ordre et nouveau contrôle social (Paris: Éd. La Découverte, 2008); M. Delmas-Marty, Libertés et sûreté dans un monde dangereux (Paris: Seuil, 2010).

${ }^{45}$ Art 63-1 s. 1 CPP, modified by the Law of 15 June 2000.

${ }^{46}$ J. D. Nuttens, 'Présomption d'innocence: le Parlement fait la loi', La Gazzette du Palais, 21-22 juin 2000, 2, 5.

${ }^{47}$ J. Buisson, 'La garde à vue dans la loi du 15 juin 2000', Revue de science criminelle 2001, 25, 36.

${ }^{48}$ H. Leclerc, 'La loi du 15 juin 2000 (Gaz. Pal, Bull. lég. 13 juillet, p. 263 et circ. p. 287) renforçant la présomption d'innocence et les droits des victimes', Gaz Pal, 29-30 septembre 2000, 2, 3.

${ }_{49}$ Ministry of Justice circulars follow the enactment of legislation, offering interpretation of the legislative text enacted and specific guidance relating to its application.

${ }^{50}$ Circulaire CRIM 00-13 F1 du 4 décembre 2000, présentant les dispositions de la loi du 15 juin 2000 renforçant la protection de la présomption d'innocence et les droits des victimes concernant la garde à vue et l'enquête de police judiciaire, para 2.1.
} 
where preoccupations with security and law and order dominated the political agenda. $^{51}$

This led to the amendment of the wording of the caution in March 2002. Remaining silent would now be presented as only one of different options available to the suspect, who would be informed that he could 'make a statement, answer the questions posed to him or remain silent'. ${ }^{52}$ Not many will disagree that a caution of this type demonstrates little enthusiasm for the exercise of the right. Just in case there are any doubts, the relevant Law circular should cause them to evaporate. It clarified that 'the right not to respond to questions posed by the investigators [should] not be perceived by persons subjected to the garde à vue as an incitement to remain silent'. 53 These changes were implemented by a Socialist government that had introduced the notification duty in much stronger terms only two years earlier. A new government of the Right with a strong focus on security and public order ${ }^{54}$ then gave the right to silence the final blow, with legislation passed in March 2003, mainly as a result of pressures exercised by magistrates and the police. ${ }^{55}$ This legislation removed the duty to notify suspects of their right to remain silent altogether. In less than three years, France had thus gone from finally obliging the police to notify suspects of their right to silence to compromising considerably its application in practice, and then to abolition.

In conclusion, until the Law of 14 April 2011, France had strongly resisted two reforms capable of enhancing the adversarial character of the garde à vue. Access to custodial legal advice and presence of counsel during questioning, on the one side, notification of the right to silence, on the other, can strengthen the informed and voluntary participation of suspects in custodial interrogation but at the same time have the potential to obstruct truth discovery. Perhaps then, from the local viewpoint of a legal system that has evolved through the years with the objective of truth discovery primarily in mind, ${ }^{56}$ there was nothing peculiar about the resistance to these two adversarial reforms. As will be demonstrated below, however, such unbending insistence upon inquisitorialism was myopic, failing to take into account that the above two rights were fast growing in significance - not only in their traditional adversarial strongholds but also in inquisitorial fields where conditions for their fertilization were far from ideal - and that international law has progressively become suspicious of suspects' isolation and disempowerment at this crucial stage of the criminal process.

\footnotetext{
${ }^{51}$ See Hodgson, French Criminal Justice (n 9 above) 39.

${ }^{52}$ Art 63-1 CPP s. 1 CPP modified by the Law of 4 March 2002 (Loi n ${ }^{\circ}$ 2002-307 du 4 mars 2002 complétant la loi $\mathrm{n}^{\circ} 2000-516 \mathrm{du} 15$ juin 2000 renforçant la protection de la présomption d'innocence et les droits des victimes).

${ }^{53}$ CRIM-02-07-E8 du 19 mars 2002 présentant les dispositions de la loi du 4 mars 2002 qui complètent la loi $\mathrm{n}^{\circ}$ 2000-516 du 15 juin 2000, laquelle renforce la protection de la présomption d'innocence et les droits des victimes.

${ }^{54}$ Hodgson, French Criminal Justice (n 9 above) 48.

${ }^{55}$ C. Lazerges, 'La dérive de la procédure pénale', Revue de science criminelle 2003, 644, 647.

${ }^{56}$ See generally J. Spencer, 'La procédure pénale française vue par un Anglo-Saxon' in Cour de cassation, La procédure pénale en quête de cohérence (Paris: Dalloz, 2007) 227, 233.
} 


\subsection{Foreign and International Law Perspectives}

Prior to the 2011 reforms, French legislation on custodial interrogation was 'a long way from satisfying European mandates', according to Matsopoulou, ${ }^{57}$ while Lazerges spoke of an isolation of French texts and practice, and of 'a French exception', notably on the issue of lawyers' presence at the garde à vue. ${ }^{58}$ Coming from the mouth of 'French' academics, these affirmations of French exceptionalism are highly significant. They resonate well with various comparative studies that confirm that most Anglo-American and European Continental legal systems recognize the right of suspects to see a lawyer and be notified of the right to silence. ${ }^{59}$

I have taken a closer look at a number of foreign legal systems to get a better picture of France's position on this issue at a global level, focusing on European Continental legal systems but also selecting examples from the common law and Asian legal traditions as well as two specific examples from Latin America and the Middle East. The following countries served as comparators: Canada, the United States, Argentina, Ireland, England and Wales, Scotland, Denmark, the Netherlands, the Russian Federation, Germany, Austria, Belgium, Spain, Italy, Greece, Slovenia, Israel, Nigeria, South Africa, India, Japan and China. ${ }^{60}$ My inquiries were limited to

57 H. Matsopoulou, 'Garde à vue: la Cour de cassation partagée entre conventionnalité et constitutionnalité - À propos des arrêts de la chambre criminelle du 19 octobre 2010', La semaine juridique 2010, 2096.

${ }_{58}$ C. Lazerges, 'Les désordres de la garde à vue', Revue de science criminelle 2010, 275.

${ }^{59}$ See G. Van Kessel, 'European Perspectives on the Accused as a Source of Testimonial Evidence', 100 West Virginia Law Review 799, 808 (1997-1998); C. Bradley (ed), Criminal Procedure: A Worldwide Study (Durham: Carolina Academic Press, 1999) 428; S. Thaman, 'Miranda in Comparative Law', 45 St Louis University Law Journal 581, 618 (2001); S. Thaman, 'The Two Faces of Justice in the Post-Soviet Legal Sphere: Adversarial Procedure, Jury Trial, Plea-Bargaining and the Inquisitorial Legacy' in Jackson, Langer and Tillers (eds) (n 10 above) 99, 102; T. Spronken and others, EU Procedural Rights in Criminal Proceedings (2009) 32 <http://arno.unimaas.nl/show.cgi?fid=16315> accessed 5 October 2012; Justice, Intervention in $H M$ Advocate v. Cadder [2010] UKSC 43, 30 April $2010<\mathrm{http}: / / w w w . j u s t i c e . o r g . u k / p a g e s / c a d d e r-v-h m-$ advocate.html> accessed 5 October 2012.

${ }^{60}$ I am grateful to Dr Saif Mahmood, Advocate at the Supreme Court of India, and Mr Orowhuo Okocha, my PhD student, for their information on India and Nigeria respectively. For information on legal assistance and notification of the right to silence in the countries examined here see R. Harvie and H. Foster, 'When the Constable Blunders: A Comparison of the Law of Police Interrogation in Canada and the United States', 19 Seattle University Law Review 497 (1995-1996); Van Kessel, ibid.; Bradley, ibid.; Thaman, ibid.; C. Bateman, 'Dickerson v. United States: Miranda is Deemed a Constitutional Rule, but Does it Really Matter?', 55 Arkansas Law Review 177 (2002); Y. Ma, 'The Powers of the Police and the Rights of Suspects under the Amended Criminal Procedure Law of China', 26 Policing: An International Journal of Police Strategies and Management 490 (2003); B. L. Arora, Law of Speedy Trial in India (New Delhi: Universal Law Publishing, 2006); N. Androulakis, Fundamental concepts of the criminal trial (Athens: P. N. Sakkoulas, 2007) 360-364 (in Greek); Japan Federation of Bar Associations, Report on the Japanese Government's Implementation of the Convention Against Torture, January 18, 2007; Irish Human Rights Commission, Submission to the UN Human Rights Committee on the Examination of Ireland's Third Periodic Report on the ICCPR, March 2008; J. Pradel, Droit pénal comparé (Paris: Dalloz, 2008); Amnesty International, Out of the Shadows: Time to End Incommunicado Detention (Amnesty International Publications 2009); Y. M. Daly, 'Is Silence Golden? The Legislative and Judicial Treatment of Pre-Trial Silence in Ireland' (2009) 31 Dublin University Law Journal 35; Sénat, La garde à vue, Les documents de travail du Sénat - Série législation comparée, 2009, $\mathrm{n}^{\circ}$ LC 204; E. Cape and others, Effective Criminal Defence in Europe: Executive Summary and Recommendations (Antwerp-Oxford-Portland: Intersentia, 2010) <http://pdc.ceu.hu/archive/00006287/01/criminal-defence-europe-summary.pdf>, accessed 5 October 2012; L. Li and Y. Ma, 'Adjudications and Legal Reforms in Contemporary China' (2010) 26 Journal of Contemporary Criminal Justice 36; V. R. Manohar, Ratanlal \& Dhirajlal's The Code of Criminal 
establishing whether legislation in these countries provides for notification of the right to silence, access to legal assistance at the police station and the presence of a lawyer during questioning. The answers lead one to paint a bleak picture of French criminal procedure's cosmopolitanism. First of all, of these twenty-two countries, only the Russian Federation, Greece, India and China do not provide for notification of the right to silence. Belgium has only recently recognized this right, with legislation enacted in August 2011. ${ }^{61}$ France was in the same league with these countries until the 2011 reform, with the exception of the period between 2000 and 2003. Secondly, of the surveyed countries, only China does not give suspects access to legal counsel today. Scotland, the Netherlands and Belgium had until recently adopted a similar position, ${ }^{62}$ but developments sparked by Salduz $v$ Turkey ${ }^{63}$ have now led to recognition of this right. ${ }^{64}$ France had not provided for any legal assistance until the 1993 reforms. It was only after the June 2000 reforms that suspects finally obtained the right to consult with a lawyer from the beginning of the interrogation but, again, not in the many cases relating to terrorism, drug trafficking and other organized crime offences. One can conclude from the above that France had long set its face against the international consensus on this matter. A more equivocal picture is painted if one looks at whether the above countries allow suspects to have their lawyer present

Procedure (19 ${ }^{\text {th }}$ edn, Gurgaon: LexisNexis Butterworths Wadhwa Nagpur, 2010) 110; A. Giudicelli and C. Juhász, 'La "garde à vue" dans la legislation autrichienne', Revue de science criminelle 2011, 59; R. Pattenden, 'Right to Counsel at the Police Station - United Kingdom and Canada' (2011) 15 E \& P 70; C. Boyle and E. Cunliffe, 'Right to Counsel During Custodial Interrogation in Canada: Not Keeping Up with the Common Law Joneses' in P. Roberts and J. Hunter, Criminal Evidence and Human Rights: Reimagining Common Law Procedural Traditions (Oxford: Hart Publishing, 2012) 79; M. Bohlander, Principles of German Criminal Procedure (Oxford: Hart Publishing, 2012) 95; S. Schuman, K. Bruckmüller and R. Soye, Pre-Trial Emergency Defence (NWV/ Intersentia 2012). See UN Committee against Torture reports: Argentina, List of Issues, CAT/C/ARG/Q/5-6, 2/8/2010; Belgium, Concluding observations, CAT/C/BEL/CP/2, 19/1/2009; China, Concluding observations, CAT/C/CHN/CO/4, 12/12/2008; Japan, Report submitted by State Party, CAT/C/JPN/1, 21/3/2007; Japan, Conclusions and recommendations, CAT/C/JPN/CO/1, 3/8/2007; The Netherlands, Conclusions and recommendations, CAT/C/NET/CO/4, 3/8/2007; Spain, Concluding observations, CAT/C/ESP/CO/5, 9/12/2009. See European Committee for the Prevention of Torture Reports: CPT Report to the Spanish Government, CPT/ Inf (2011) 11, 25/3/2011. See CCPR reports: The Netherlands, Concluding observations, CCPR/C/NLD/CO/4, 25/8/2009. On India see also DK Basu v State of West Bengal (1997) 21 ACR 277.

${ }^{61}$ Art 2 de la Loi du 13 août 2011 <http://www.etaamb.be/fr/loi-du-13-aout-2011_n2011009606.html> accessed 5 October 2012.

${ }^{62}$ Under the Criminal Procedure (Scotland) Act 1995, s. 14, which has consolidated the Criminal Justice (Scotland) Act 1980, police in Scotland had the power to interrogate suspects for six hours without allowing them to consult with a lawyer. See J. R. Spencer, 'Strasbourg and Defendants' Rights in Criminal Procedure' (2011) 70 Cambridge Law Journal 14. See also D. Giannoulopoulos, " North of the Border and Across the Channel": Custodial Legal Assistance Reforms in Scotland and France' [2013] Crim LR (forthcoming). In Belgium, article 20 of the Pretrial Detention Act of 20 July 1990 provided that accused persons would be permitted to communicate freely with their lawyer only after the initial hearing before the investigating judge. See UN Committee against Torture, Follow-up replies from the Government of Belgium to the concluding observations of the Committee against Torture, CAT/C/BEL/CO/2, 28/3/2011, para 74 .

${ }^{63}$ Above (n 1).

${ }^{64}$ In Scotland, the Criminal Procedure (Legal Assistance, Detention and Appeals) (Scotland) Act 2010 gave suspects the right to have a private consultation with a solicitor before any questioning by a constable begins and at any other time during such questioning. In the Netherlands, the Supreme Court held that 'a suspect arrested by the police must be offered the opportunity to consult a lawyer before being interviewed'. LJN BH3079, 30 June 2009, cited by Cadder v. HM Advocate [2010] UKSC 43, para 49. In Belgium, the Law of 13 August 2011 gave suspects the right to meet with a lawyer for thirty minutes at the beginning of the detention period, before being questioned by the police. 
during questioning. More than half of the countries examined here recognize such a right. ${ }^{65} \mathrm{By}$ way of contrast, France was a long way from endorsing this due process centred position throughout the 1990s and the last decade; access to a lawyer is still today severely restricted when exceptional regimes of garde à vue are set in motion.

It is equally useful to investigate whether these countries afford suspects the full panoply of the above-mentioned rights. The fact that the majority of them allow suspects to exercise all three rights signifies the importance of adversarial safeguards in modern criminal procedure. ${ }^{66}$ Some other countries recognize only two of these rights. Thus, in Canada, Germany, Ireland and Japan, suspects are entitled to consult a lawyer and be notified of their right to silence but not to have a lawyer present during interrogation, whereas in Greece and the Russian Federation, suspects can consult a lawyer and be questioned in his presence, but they are not notified of their right to silence. Suspects in India are only entitled to access to counsel, whereas China recognizes none of these rights. This was also the position in Belgium until the August 2011 legislation came into force. Against this comparative law background, French exceptionalism quickly reveals itself. Until 1993, none of these rights applied in France, while immediately prior to the 2011 reforms, suspects were only still entitled to the right to access to counsel.

At this point, it may be wise to sound a note of caution. The fact that the above countries have legislated some or all the rights examined here does not say much about how effectively they implement them in practice. Be that as it may, at least the vast majority of these countries start from the legal position that these rights must be guaranteed. In contrast, France has until recently taken a principled position that these rights do not merit protection at this phase of the criminal process, proving that it has long been out of keeping with developments in countries in its European neighbourhood and the rest of the world.

The long-term insistence on a predominantly inquisitorial model of police interrogation demonstrates that France has also been out of keeping with important developments at the level of international law, most notably the rise to pre-eminence, in international criminal tribunals and the International Criminal Court, of adversarial procedural guarantees taking their root at the right to fair trial. ${ }^{67}$ The statutes of these international criminal courts have invariably provided for the suspects' right to be informed of their right to silence prior to questioning, to have legal assistance and to be questioned in the presence of counsel. ${ }^{68}$ Furthermore, international human rights instruments have sanctioned the right to legal assistance, ${ }^{69}$ albeit in a more cryptic manner as to its particular applications at the police interrogation stage. Human rights treaty bodies and committees have been more categorical about the obligations for

\footnotetext{
${ }^{65}$ These are Italy, Spain, Greece, Slovenia, England and Wales, Denmark, Austria, the Russian Federation, the United States, Nigeria, South Africa, Argentina and Israel. Belgium has just introduced this right. See art 2bis of the Law of 13 August 2011. In relation to Argentina, it must be noted that the Code of Criminal Procedure provides that suspects will only be interrogated by the investigating judge and not by the police. When suspects appear before the investigating judge, they are entitled to have a lawyer present and are informed of their right to silence. See A. D. Carrió and A. M. Garro, 'Argentina' in C Bradley, Criminal Procedure: A Worldwide Study (Durham, North Carolina: Carolina Academic Press, 2007) 3, 29.

${ }^{66}$ These are England and Wales, the United States, Nigeria, South Africa, Denmark, Austria, Spain, Italy, Slovenia, Israel, Argentina and, since August 2011, Belgium as well.

${ }^{67}$ See P. Roberts, 'Faces of justice Adrift?' (n 13 above) 326; A. Cassese, International Criminal Law $\left(2^{\text {nd }}\right.$ edn, OUP 2008) 353.

${ }^{68}$ See eg Rule 42 ICTY and ICTR Rules of Procedure and Evidence; art 55(2) Rome Statute; art 15

Statute of the Special Tribunal for Lebanon.

${ }^{69}$ See T. Spronken and others (n 59 above) 21.
} 
state parties stemming from this right. The Committee against Torture, for instance, has insisted that persons in police custody should have access to legal counsel from the outset of their deprivation of liberty. In its 2010 concluding observations on France, the Committee asked that the latter should take 'appropriate legislative measures to guarantee immediate access to a lawyer during police custody'. ${ }^{70}$ In the same vein, the European Committee for the Prevention of Torture has declared that 'access to a lawyer for persons in police custody should include the right to contact and to be visited by the lawyer ... as well as, in principle, the right for the person concerned to have the lawyer present during interrogation' ${ }^{71}$ In its 2007 report to France, it was also most evident that the Committee was losing patience with the country's continued attempts to circumvent the right to consult with a lawyer. The report explained that the Committee had 'already developed in length, and for several years, the arguments in favour of access to counsel from the first hour of deprivation of liberty by law enforcement authorities, including in relation to the most serious offences'. ${ }^{72}$ The Committee of Ministers of the Council of Europe has made similar recommendations to member states. ${ }^{73}$

At the supranational level, the European Commission's 2004 proposal for a framework decision on certain procedural rights throughout the European Union is particularly noteworthy. It contained rules aimed at reinforcing suspects' access to legal advice and notification of their rights at the police station. ${ }^{74}$ Efforts to create common minimum standards on the rights of suspects across the EU have gained momentum more recently, with a 2009 Roadmap for procedural safeguards ${ }^{75}$ that led to a proposal for a Directive on the right to access to lawyer and the right to communicate upon arrest. ${ }^{76}$ The proposed Directive provides for access to a lawyer as soon as practically possible from the outset of deprivation of liberty and before the start of any questioning, ${ }^{77}$ and for lawyers' presence and active role during questioning. ${ }^{78}$ The Roadmap also led to the adoption of a Directive on the right to information. Article 3 of the Directive provides that member states shall ensure that suspects are provided promptly with information concerning at least certain procedural rights. The right to silence features within these rights. ${ }^{79}$

In view of the above, France's parochial attitude to police detention and interrogation cannot be easily reconciled with the idea of a fast-growing legal cosmopolitanism. The next step in this line of thinking is to take the example of France to illustrate that the growing cosmopolitanism argument may be exaggerated and that generalizations about modern legal systems' openness to each other and receptivity of international law may have to be approached with greater caution.

\footnotetext{
${ }^{70}$ Annual Report, A/65/44, 2009-10, 95.

${ }^{71}$ CPT Standards, CPT/Inf/E (2002) 1 - Rev 2010, para 38.

${ }^{72}$ Emphasis added. Rapport au Gouvernement de la République française relatif à la visite effectuée en France par le Comité européen pour la prévention de la torture et des peines ou traitements inhumains ou dégradants (CPT), du 27 septembre au 9 octobre 2006, CPT/Inf (2007) 44, paras 38-39.

${ }^{73}$ See Salduz v. Turkey (n 1 above) paras 37-38.

${ }^{74} \operatorname{COM}(2004) 328,28 / 4 / 2004$.

${ }^{75}$ OJ C 295, 4/12/2009.

${ }^{76} \operatorname{COM}(2011) 326,8 / 6 / 2011$. For the revised text, see Council of the European Union 7337/ 12, 9 March 2012.

${ }^{77}$ Ibid., art 2.

${ }^{78}$ Ibid., art 3.

${ }^{79}$ Directive 2012/13/EU of the European Parliament and of the Council of 22 May 2012 on the right to information in criminal proceedings.
} 


\section{LEGAL COSMOPOLITANISM AND LEGAL REFORM}

Pre-April $14^{\text {th }}$ exceptionalism does not appear to be the result of isolation from influences of foreign and international law. In addition to the many treaty body reports criticizing the garde à vue, many French research studies had exposed the gap separating indigenous custodial interrogation practices from those endorsed by foreign countries and international law. For the purposes of illustration, if we go as far back as 1991, we see that the report of the Commission Delmas-Marty had relied heavily on comparisons of custodial interrogation rules in Anglo-American and Continental legal systems. ${ }^{80}$ Likewise, a report attached to the June 2000 legislation explained that the provisions on legal assistance aimed to 'harmonise [French] law with the legislation of the principal European countries, which [had] already [been] providing, often for several years, for the intervention of a lawyer from the beginning of the interrogation'. ${ }^{81}$ In short, in France there was undoubtedly an awareness that the garde à vue was falling short of European and international standards giving custodial interrogation an adversarial character. The willingness to bring the garde à vue into line with such standards was apparently missing. This changed only when the ECtHR proceeded to outright rejection of certain inquisitorial traits of custodial interrogation.

In Salduz $v$ Turkey, ${ }^{82}$ where the applicant had been denied access to a lawyer while in police custody, the Grand Chamber of the ECtHR underlined the suspect's particularly vulnerable position at the investigation stage, noting that 'in most cases, this particular vulnerability can only be properly compensated for by the assistance of a lawyer ${ }^{83}$ and that 'early access to a lawyer is part of the procedural safeguards to which the Court will have particular regard when examining whether a procedure has extinguished the very essence of the privilege against self-incrimination'. ${ }^{84}$ The Court concluded that article 6(1) of the Convention requires that 'as a rule, access to a lawyer should be provided as from the first interrogation of a suspect by the police, unless it is demonstrated in the light of the particular circumstances of each case that there are compelling reasons to restrict this right', ${ }^{85}$ and that ' $[\mathrm{t}]$ he rights of the defence will in principle be irretrievably prejudiced when incriminating statements made during police interrogation without access to a lawyer are used for a conviction'. 86

\footnotetext{
${ }^{80}$ Commission Justice pénale et droits de l'homme, La mise en état des affaires pénales (n 31 above).

${ }^{81}$ Exposé des motifs du projet de loi renforçant la protection de la présomption d'innocence et des droits des victimes <http://lesrapports.ladocumentationfrancaise.fr/BRP/004001243/0000.pdf> accessed 5 October 2012. For another example, see the report of the Outreau Commission. Assemblee nationale, Rapport fait au nom de la Commission d'enquête chargée de rechercher les causes des dysfonctionnements de la justice dans l'affaire dite d'Outreau et de formuler des propositions pour éviter leur renouvellement, $\mathrm{n}^{\circ} 3125$ (2006) 197 <http://www.assemblee-nationale.fr/12/pdf/rapenq/r3125-t1.pdf> accessed 5 October 2012. The Commission that investigated the Outreau affair, a miscarriage of justice with catastrophic consequences for French criminal justice, proposed reforms relating to the assistance of counsel that would 'better subscribe the garde à vue procedure to European norms pertaining to human rights of the defendant'. See generally G Giudicelli-Delage, 'La juste distance... Réflexions autour de mauvaises ( ?) questions. A propos de la réforme de l'instruction et de la procédure pénale française' in Mélanges dédiés à Bernard Bouloc, Les droits et le droit (Paris: Dalloz, 2007) 389.

${ }^{82}$ (2008) EHRR 421.

${ }^{83}$ Salduz v. Turkey (n 1 above) para 54.

${ }^{84}$ Ibid.

${ }^{85}$ Ibid., at para 55.

${ }^{86}$ Ibid.
} 
In Dayanan $v$ Turkey the Court clarified that the right to effective legal assistance requires that a suspect should be assisted by a lawyer 'as soon as he or she is taken into custody ... and not only while being questioned'. ${ }^{87}$ The Court observed that a suspect should be able to:

obtain the whole range of services specifically associated with legal assistance. In this regard, counsel has to be able to secure without restriction the fundamental aspects of that person's defence: discussion of the case, organisation of the defence, collection of evidence favourable to the accused, preparation for questioning, support of an accused in distress and checking of the conditions of detention. ${ }^{88}$

The French solution of two thirty-minute meetings in 48 hours of interrogation, without access to the investigation dossier, could not possibly satisfy the fair trial requirements set by the ECtHR. ${ }^{89}$ Lawyers in France were the first to take notice of this development, relying on the Court's jurisprudence to stigmatize the illegal character of the garde à vue. ${ }^{90}$ The government's initial reaction, on the other hand, was to downplay the importance of ECtHR decisions not condemning France, though there was also recognition of the need to rethink the garde à vue. ${ }^{91}$ However, it was the judiciary that was most influenced by the winds of change blowing from Strasbourg, as evidenced by the fact that certain jurisdictions put immediately into application the principles laid down by its jurisprudence, thus nullifying garde à vue measures in cases where suspects had not been assisted by a lawyer. ${ }^{92}$ These were first instance or even pre-trial jurisdictions applying the ECtHR jurisprudence at a time when higher courts had not yet spoken on the issue.

This change of attitudes towards custodial interrogation coincided with the introduction in March 2010 of an a posteriori and abstract control of constitutionality, known as question prioritaire de constitutionnalite (QPC), ${ }^{93}$ allowing for the first time individual parties to request that the Conseil constitutionnel (Constitutional Council) should examine the constitutionality of legislation that may be applicable to litigation in which they are involved. The very first day the QPC came into effect, an application was made targeting a number of garde à vue provisions in the Code de

\footnotetext{
${ }^{87}$ App no 7377/ 03 (ECtHR, 13 October 2009), para 32.

${ }^{88}$ Ibid. See also Adamkiewicz c. Pologne, App No 54729/00 (ECtHR, 2 March 2010).

${ }^{89}$ See J.F. Renucci, 'L'avocat et la garde à vue: exigences européennes et réalités nationales', Recueil Dalloz 2009, 2897; J. Alix, 'Les droits de la défense au cours de l'enquête de police après la réforme de la garde à vue: état de lieux et perspectives', Recueil Dalloz 2011, 1699, paras 17-18.

${ }^{90}$ Renucci, ibid. 2897.

${ }^{91}$ Ibid. See also Lazerges, 'Les désordres de la garde à vue' (n 58 above) 275; Pradel, 'Vers une métamorphose de la garde à vue’ (n 28 above) 2783.

92 Matsopoulou, 'Garde à vue: la Cour de cassation partagée entre conventionnalité et constitutionnalité' (n 61 above) 2094. See also A. Maron and M. Haas, 'Tandis que les gardes à vues explosent, la garde à vue implose...', Droit pénal 2010, 10; J. Hodgson, 'The French Prosecutor in Question', 67 Washington \& Lee Law Review 1361, 1401 (2010).

${ }^{93}$ See art 61-1(4) and 62(5) of the Constitution, introduced with Constitutional Law $\mathrm{n}^{\mathrm{o}}$ 2008-724 and Organic Law no 2009-1523 of 10 December 2009. On the QPC see M. Guillaume, 'Question prioritaire de constitutionnalité et Convention européenne des droits de l'homme', Nouveaux cahiers du Conseil constitutionnel 2011, 67; M. Hunter-Henin, 'Constitutional Developments and Human Rights in France: One Step Forward, Two Steps Back' (2011) 60 ICLQ 167; C. Lazerges, 'La question prioritaire de constitutionnalité devant le Conseil constitutionnel en droit pénal: entre audace et prudence', Revue de science criminelle 2011, 193.
} 
procédure pénale (Code of Criminal Procedure), ${ }^{94}$ and in a much anticipated decision, on 30 June 2010, the Conseil constitutionnel made a finding of unconstitutionality vis-à-vis each one of the provisions it had examined. ${ }^{95}$ The Court noted in particular that a person undergoing questioning did not 'have the benefit of the effective assistance from a lawyer' 96 and that 'such a restriction on the rights of the defence [was] imposed as a general matter without any consideration of particular circumstances likely to justify it'. ${ }^{97}$ The Court also paid attention to the fact that suspects were not being informed of their right to remain silent. ${ }^{98}$

The ECtHR's influence is apparent in the above insistence on effective legal assistance and the rejection of restricting defence rights solely on the basis of the nature of the offence under investigation. Further proof of such influence can be found in the oral arguments before the Court that contained many references to Salduz and ECHR jurisprudence. ${ }^{99}$ We can explore the same thought by means of a 'what if' question, asking whether the Conseil constitutionnel would have reached the same decision if Salduz had not happened. Bertrand de Lamy answered the question in the negative. As he explained, the Conseil constitutionnel suddenly struck down the garde à vue legislation, though it had previously never questioned its constitutionality, 'surely under the influence of the European Court of Human Rights' ${ }^{100}$ André Giudicelli even more graphically illustrated this point:

Surely, we cannot but take pleasure in [the Court's] awakening, given that until now it had never questioned the legislative texts relevant to the garde à vue ... [T] his awakening is to a large extent due to a European fanfare the echoes of which have reached the windows of the Palais Royal, ${ }^{101}$ no doubt open this end of July $2010 .^{102}$

Surprisingly, however, the Conseil constitutionnel did not proceed to repealing immediately the provisions it had just found unconstitutional, postponing giving its decision any effect until 1 July 2011, eleven months later, to allow parliament to remedy the situation in the mean time. ${ }^{103}$ Even in this way, the decision of the Conseil

\footnotetext{
${ }^{94} \mathrm{P}$. Robert-Diard, 'Nouvelle offensive des avocats contre les conditions de garde à vue: Ils veulent profiter de l'entrée en vigueur d'une disposition de la réforme constitutionnelle', Le Monde (Paris, 2 March 2010) discussed by Hodgson, 'The French Prosecutor in Question' (n 92 above) 1403.

${ }^{95}$ Conseil constitutionnel, Décision n ${ }^{\circ} 2010-14 / 22$ QPC du 30 juillet 2010, available in English at <http://www.conseil-constitutionnel.fr/conseil-

constitutionnel/root/bank/download/201014_22QPCen201014qpc.pdf> accessed 5 October 2012. On the other hand, the Court refused to examine, on technical grounds, the constitutionality of the exceptional regimes of garde à vue. See para 13 of the decision.

${ }^{96}$ Ibid., at para 28.

${ }^{97}$ Ibid.

98 Ibid.

99 See the video recordings of the public audience of July 20, 2010, <http://www.conseilconstitutionnel.fr/conseil-constitutionnel/francais/acces-videos/decisions/2010/affaires-n-2010-14-qpcet-n-2010-22-qpc.48722.html> accessed 5 October 2012.

100 'L'avancée des garanties en matière de garde à vue ou la consécration d'un basculement de la procédure pénale vers la phase policière', Revue de science criminelle 2011, 165. It must be noted here that the Court had upheld the constitutionality of the relevant provisions of the garde à vue legislation on many occasions in the past, in the context of the ex ante control of constitutionality that the Conseil constitutionnel traditionally undertakes in France.

${ }^{101}$ The Palais Royal in Paris houses the Conseil constitutionnel.

102 'Le Conseil constitutionnel et la garde à vue: puisque ces mystères nous dépassent, feignons d'en être l'organisateur', Revue de science criminelle 2011, 139.

${ }^{103}$ Conseil constitutionnel, Décision n ${ }^{\circ} 2010-14 / 22$ QPC du 30 juillet 2010 (n 95 above), para 30.
} 
constitutionnel, along with ECHR jurisprudence, served as a foundation for the decisions of the Cour de cassation (Supreme Court of France) that led to the institution of a new regime of garde à vue even before the Law of April $14^{\text {th }}$ came into effect.

On October $19^{\text {th }}$, three judgments of the plenary session of the Cour de cassation (assemblée plenière) ${ }^{104}$ struck the first blow. The Court found that for the requirements of article 6 of the Convention to be satisfied, the suspect must not be questioned in the absence of his lawyer, ${ }^{105}$ that he must be informed of the right to silence and be assisted by a lawyer from the beginning of the garde à vue, unless there are compelling reasons to restrict the right or the suspect has unequivocally waived his right, ${ }^{106}$ and, finally, that the right to access to a lawyer cannot be restricted solely on the basis of the nature of the offence concerned. ${ }^{107}$ In brief, taking its inspiration directly from the jurisprudence of the ECtHR, the Cour de cassation placed legal assistance during police questioning and notification of the right to silence at the centre of the garde à vue. However, aligning itself with the Conseil constitutionnel as well, the Court stopped short of giving immediate effect to the rules it announced, postponing their application until 1 July 2011.

These decisions were published only five days after the ECtHR, in Brusco $v$. France, condemned France for the first time for shortcomings of the regime of the garde à vue, in a case where the suspect had not been notified of his right to silence and had not been assisted by a lawyer until twenty hours of interrogation had passed. In line with Salduz and Dayanan, the ECtHR noted that a person subjected to a garde $\grave{a}$ vue 'has the right to be assisted by a lawyer from the beginning of this measure as well as during questioning, and this is a fortiori the case when he has not been informed by the authorities of his right to silence'. ${ }^{108}$ This decision was a turning point for the reform of custodial interrogation à la française. Until then, ECHR case law on custodial interrogation was being dismissed by some as 'having no obligatory force upon France, which had never been condemned by the ECtHR on that subject'. 109

In any case, the Cour de cassation continued its assault on the garde à vue unabated. With its January 2011 decisions ${ }^{110}$ the Court confirmed that the new rules on effective legal assistance would not come into effect until the deadline set by the Conseil constitutionnel had passed or new legislation had been introduced, but at the same time, it found that confessional evidence obtained in the course of the garde $a$ vue, without the suspect benefiting from effective legal assistance, was inadmissible in trial and that this rule was going to have immediate effect. This meant that the now well-established incompatibility of the garde à vue with the ECHR was not going to be emptied of substance as a result of the suspended effect of the decision of the Conseil constitutionnel. ${ }^{111}$ The ECtHR's grip upon the Cour de cassation is manifest

\footnotetext{
${ }^{104}$ A total of 19 judges sit in plenary sessions of the Court, which hear cases when a matter of principle is involved. See The Court of Cassation, 'The Role of the Court of Cassation' <http://www.courdecassation.fr/about_the_court_9256.html > accessed 5 October 2012.

${ }^{105}$ Crim 19 octobre 2010, Bull crim 163.

${ }^{106}$ Crim 19 octobre 2010, Bull crim 164

${ }^{107}$ Crim 19 octobre 2010, Bull crim 165.

${ }^{108}$ Brusco v. France, App no 1466/07 (ECtHR, 19 October 2010), para 45. See also J.F. Renucci, 'Garde à vue et CEDH: la France condamnée à Strasbourg', Recueil Dalloz 2010, 2950.

${ }^{109}$ Pradel, 'Vers une métamorphose de la garde à vue' (n 28 above) 2783, para 3.

${ }^{110}$ Crim 4 janvier 2011, $\mathrm{n}^{\circ}$ 10-85.520, Recueil Dalloz 2011, 242, obs M. Léna; Crim 18 janvier 2011, $\mathrm{n}^{\circ}$ 10-83.750, Recueil Dalloz 2011, 381. See also 16 février 2011, n 10-82.865, Recueil Dalloz 953.

111 J. Danet, 'Une non-conventionnalité bien réelle', Revue de science criminelle 2011, 144.
} 
here; the French conception of custodial interrogation had to give way to that now exported by the European judges.

The Cour de cassation, again in a plenary session, drove that point home with its seminal decisions of April $15^{\text {th }} .112$ The decisions coincided with the publication of the Law of 14 April 2011, which was to take effect on June $1^{\text {st }}$. In this instance, the Court opted for the immediate effect of the jurisprudence of the ECtHR, underlining that 'the states adhering to the Convention .... are held to respect the decisions of the European Court of Human Rights, without waiting to be taken to it first nor to have modified their legislation'. ${ }^{113}$ In so doing, the Cour de cassation broke loose from the influence of Conseil constitutionnel jurisprudence to give primacy to that of the ECtHR. ${ }^{114}$ It also left the government no room to manoeuvre, forcing it to follow in its steps, as evidenced by the immediate press release of the Minister of Justice, instructing prosecutors to apply without delay the rules of the Law of April $14^{\text {th }}$ pertaining to assistance during questioning and notification of the right to silence.

Then, on May $31^{\text {st }}$, the Cour de cassation went so far as to give its decisions full retroactive effect. The Court found violations of the right to a fair trial in four cases where suspects had been subjected to custodial interrogation prior to the coming into effect of the rules adopted by the assemblée plenière on April $15^{\text {th }}$. The suspects had neither been notified of their right to remain silent nor been assisted by a lawyer from the beginning of the garde à vue. ${ }^{115}$ These were remarkable decisions, especially if one considers that they had the ability to lead to thousands of measures of garde $\grave{a}$ vue being retroactively nullified. ${ }^{116}$

Considered in the round, France's reception of Salduz and its aftermath merits special attention, particularly since it seems to discord with previous observations about French reservations towards giving effect to the European Convention. ${ }^{117}$ The mere speed and stealth with which the Cour de cassation has attempted to transform the French garde à vue since Salduz and Dayanan, and even more so since Brusco, is testament to both the ECHR's power to transform national law and France's ability to accommodate such transformative power. It is important to note here that since the end of the 90s the Cour de cassation had been making considerable efforts to reinforce suspects' rights at the police station - mainly by developing a jurisprudence of automatic 'exclusion' of confessional evidence obtained in violation of custodial

\footnotetext{
${ }^{112}$ Crim 15 avril 2011, 4 arrêts ( ${ }^{\circ} \mathrm{P} 10-17.049$, F 10-30.313, J 10-30.316 et D 10-30.242), Recueil Dalloz 2011, 1080; Recueil Dalloz 2011, 1128, entretien G. Roujou de Boubée; JCP 2011, n 17, 483, S. Détraz.

${ }^{113}$ Ibid.

${ }^{114}$ See A. Levade, 'Quand la foudre frappe deux fois ou comment la Cour de cassation impose son rythme à la réforme de la garde à vue !', Constitutions 2011, 326; H. Matsopoulou, 'Garde à vue: primauté de la jurisprudence européenne sur les règles constitutionnelles', Recueil Dalloz 2011, 2084.

${ }^{115}$ Crim 31 mai 2011, n 11-81.412, 10-88.809, 10-80.034 et 10-88.293, Recueil Dalloz 2011, 1563.

${ }^{116}$ See J. Pradel, 'Procédure pénale: septembre 2010 - août 2011', Recueil Dalloz 2011, 2231. See also Alix (n 89 above) 1699, para 22.

${ }^{117}$ See Hodgson, 'Codified Criminal Procedure and Human Rights' (n 27 above) 168-73; Hodgson, French Criminal Justice (n 9 above) 32-38; N. Krisch, 'The Open Architecture of European Human Rights Law' (2008) 71(2) MLR 183, 191. Lambert Abdelgawad and Weber have recently noted that 'the logic of the Court of Cassation, which favours maintaining the national [criminal procedure] model, remains in opposition to the ECtHR's reasoning in favour of a harmonization of the diverse models in Europe'. E. Lambert Abdelgawad and A. Weber, 'The Reception Process in France and Germany' in H. Keller and A. Stone Sweet (eds), A Europe of Rights: The Impact of the ECHR on National Legal Systems (Oxford: OUP, 2008) 130. On the ECHR's influence on French law see generally J.P. Costa, 'La jurisprudence de la Cour européenne des droits de l'homme et son influence en France’ (2009) 57 Nomiko Bima 9.
} 
interrogation rights -, and yet, as we have seen above, it was only ECHR jurisprudence that allowed for more drastic reform in this area. This points directly to Law's increasing cosmopolitanism, especially if one takes into account that the radical reforms inspired by Strasbourg happened against the backdrop of two centuries of incremental development in the area of police interrogation in France. ${ }^{118}$

Emphasis can be added to this observation if we take into consideration previous failed attempts to remove inquisitorial aspects of the garde à vue. We have seen that criticism of the garde à vue from within the legal system was consistently met with resistance and in the end, it was only criticism from without that made it possible to overcome such resistance and lead to considerable change. Nevertheless, attention needs to be called to the fact that it was specifically the ECtHR that mandated reform in this case, whereas criticism originating from treaty body reports or comparisons with foreign legal systems had failed to instigate any change. No attention had been paid to the more adversarial position adopted by international criminal tribunals and the International Criminal Court either.

The ECtHR's impact in this domain signifies cosmopolitan Law's capacity to act as a driving force for legal reform, echoing Delmas-Marty's observation that the Court 'obliges States to legislate in domains ... where no one dared venture, or to shift a long-standing and subtle balance of powers'. ${ }^{119}$ Nonetheless, caution is again required when extrapolating legal systems' cosmopolitan attitudes from the influence that Strasbourg jurisprudence may be exercising upon them. More specifically, particular weight must be attached to the ECtHR's privileged position in the international law landscape. The ECHR overrides national law in many European countries, ${ }^{120}$ including France, ${ }^{121}$ and these countries most of the time introduce legislative changes to accommodate the Court's findings. ${ }^{122}$ The ECtHR is praised for its effectiveness in inspiring human rights reform; Heifer describes it as 'the crown jewel of the world's most advanced system for protecting civil and political liberties'. ${ }^{123}$ Thus, the ECHR is 'part-and-parcel of an emergent legal cosmopolitanism'. ${ }^{124}$ It is the human rights instrument that shapes Law's cosmopolitanism par excellence. From this point of view, it is certainly important for this case study to provide affirmation of ECHR's cosmopolitan effect on the development of national legal systems. More intriguing, however, is the fact that this study pinpoints the ECHR's impact as the sole source of cosmopolitan influences on national law. More particularly, this study demonstrates that with respect to the reform of the garde à vue, legal cosmopolitanism did not extend beyond a 'forced' importation of international law and that, contrarily, there were no signs of a 'spontaneous' importation of foreign and international law. ${ }^{125}$ Put another way,

\footnotetext{
${ }^{118} \mathrm{I}$ am grateful to Professor Paul Roberts for his thoughts on this point.

${ }^{119}$ Les forces imaginantes du droit: Le relatif et l'universel (Paris: Seuil, 2004) 10.

${ }^{120}$ P. Rackow and D. Miller, 'Literature on the Internationalisation and Europeanisation of Criminal Law' (2008) 19 Criminal Law Forum 265, 267.

${ }^{121}$ See art 55 of the French Constitution.

${ }^{122}$ See C. Rozakis, 'The Particular Role of Strasbourg Case-Law in the Development of Human Rights in Europe' (2009) 57 Nomiko Bima 20, 21 (in Greek).

${ }^{123}$ L.R. Helfer, 'Redesigning the European Court of Human Rights: Embeddedness as a Deep Structural Principle of the European Human Rights Regime' (2008) 19 European Journal of International Law 125.

${ }^{124}$ P. Roberts and A. Zuckerman, Criminal Evidence (Oxford: OUP, 2010) 704.

${ }^{125}$ Delmas-Marty describes these two aspects of the importation of foreign and international law as elements of a process of 'internalisation'. See 'Introduction' in M. Delmas-Marty and S. Breyer, Regards croisés sur l'internationalisation du droit: France - Etats-Unis (Paris: Société de législation comparée, 2009) 15.
} 
France was forced to legislate in this area under the weight of potential new condemnations by the ECtHR ${ }^{126}$ rather than spontaneously opting for reform in the light of the experience of foreign legal systems or by taking into account international human rights standards, including those now embedded in international criminal procedure as well as those encapsulated by recommendations of human rights treaty bodies specifically addressing the need for reform. This approach has little resemblance to cosmopolitanism, if we perceive cosmopolitanism as the interconnection and interpenetration of different legal cultures, as a phenomenon that encompasses 'the possibility of dialogue with the traditions and discourses of others with the aim of expanding the horizons of one's own framework of meaning and prejudice'. ${ }^{127}$

In this light, manifestations of the legal cosmopolitanism phenomenon in France can be more properly described as cosmopolitan pressures coming from outside the national legal system rather than indigenous cosmopolitan attitudes spontaneously generated from within. But pressures from outside can easily be perceived as threatening national sovereignty and national legal culture and can therefore lead to local resistance.

\section{LOCAL RESISTANCE}

Salduz and its aftermath have empowered French courts to engineer a new landscape of procedural rights applying to custodial interrogation. Strasbourg's influence becomes much less visible though if one looks at the legislative process that led to the introduction of the Law of April $14^{\text {th }}$. In fact, close scrutiny allows for two important discoveries. First, some of the adversarial rights incorporated into the garde à vue with the Law of April $14^{\text {th }}$ have been resisted throughout the process, and second, despite appearances to the contrary, this legislation is still ingrained with the inquisitorial idea that the lawyer must be limited to a passive role at this stage of the process. A number of examples illustrating these two points will be provided below.

\subsection{Resistance in the Lead up to the Law of April $14^{\text {th }}$}

At the time that Salduz was decided, the President of the French Republic had just set up the Léger Commission, with the objective to undertake 'a global analysis of the state of criminal justice in France'. ${ }^{128}$ Regarding the garde à vue, the Commission was of the opinion that lawyers' presence had to be reinforced yet did not go any further than simply recommending a second thirty-minute meeting between the lawyer and the suspect 12 hours into the interrogation. Certain members were of the view that the lawyer should be present from the beginning of the garde à vue and during questioning, but the majority feared that this would jeopardize the efficient investigation of crime. ${ }^{129}$

A few months after the publication of this report, parliament rejected a proposal for a legislative amendment that would have given suspects the right to be

\footnotetext{
${ }^{126}$ This was most evident in parliamentary discussions of the Law of April 14. See Commission des lois constitutionnelles, Compte rendu ${ }^{\circ} 25$, session ordinaire de 2010-11, 9 décembre 2010.

${ }^{127}$ Held (n 16 above) 110.

128 P. Léger, Rapport du Comité de réflexion sur la justice pénale (2009) 2 < http://www.justice.gouv.fr/art_pix/sg_rapport_leger2_20090901.pdf> accessed 5 October 2012.

${ }^{129}$ Ibid. 18.
} 
assisted by a lawyer when questioned by the police. ${ }^{130}$ The proposal was explicitly drawn from Salduz and Dayanan, concluding that it was imperative and urgent to modify French legislation in order to conform with the right to fair trial'. ${ }^{131}$ Other proposals going in the direction of conformity with the ECHR had the same fate. ${ }^{132}$ The Minister of Justice had just introduced a Bill for the Reform of Criminal Procedure and parliament allegedly wanted to focus on that. ${ }^{133}$ However, the Bill proved 'modest when compared with the more ambitious and ECtHR-inspired proposals' mentioned above. ${ }^{134}$ It reproduced the recommendations of the Léger Commission, mainly an opportunity to meet with a lawyer for thirty minutes after 12 hours of interrogation, coupled with continuous legal assistance in questioning in cases where the garde à vue would be extended beyond the 24-hour time limit. ${ }^{135}$ Notification of the right to silence was not included in the Bill. The Minister of Justice at the time, Michelle Alliot-Marie, explained in an interview that in drafting the Bill the Ministry had taken into account 'many decades of jurisprudence of the Conseil constitutionnel and the ECtHR', ${ }^{136}$ but in view of the above, one may be tempted to think that Salduz and Dayanan had escaped their attention.

The decision of the Conseil constitutionnel of July $30^{\text {th }}$ was more influential, leading to the legislative Bill that formed the basis for the Law of April $14^{\text {th }}$. The Bill provided for legal assistance during questioning and notification of the right to silence, but it gave the Prosecutor the power to delay the lawyer's presence for 12 hours, while also maintaining the exceptional garde à vue regime applying to offences related to organized crime. ${ }^{137}$ More worryingly, the Bill provided for the institution of a new procedure, provocatively named audition libre ('free questioning'), which would allow the police to question consenting suspects without their being entitled to any of the rights that would normally apply at the garde à vue. ${ }^{138}$

Notwithstanding the removal of this controversial measure, ${ }^{139}$ the Bill had a smooth passage through parliament. Nevertheless, the relevant parliamentary discussions reveal that reform of the garde à vue was not particularly welcome by members of parliament, who saw the reform as being imposed upon them as a result of the jurisprudence of the ECtHR, the Conseil constitutionnel and the Cour de

\footnotetext{
${ }^{130}$ See E. Allain, 'Garde à vue: la proposition de loi rejetée, le projet de loi dévoilé', Dalloz actualité, 2 mars 2010.

${ }^{131}$ Assemblée nationale, proposition de loi visant à instituer la présence effective de l'avocat dès le début de la garde à vue, présentée par M. A. Vallini <http://www.assembleenationale.fr/13/propositions/pion2295.asp> accessed 5 October 2012.

${ }^{132}$ Hodgson, 'The French Prosecutor in Question' (n 92 above) 1403.

${ }^{133}$ G. Roujou de Boubée, 'L'assistance de l'avocat pendant la garde à vue', Recueil Dalloz 2010, 868.

${ }^{134}$ Hodgson, 'The French Prosecutor in Question' (n 92 above) 1403.

${ }^{135}$ Roujou de Boubée (n 133 above) 863. See Avant-projet du future Code de procédure pénale, version $1^{\text {er }}$ mars 2010.

${ }^{136}$ Réforme de la procédure pénale: interview de Michelle Alliot-Marie, Dalloz actualité, 15 mars 2010.

${ }^{137}$ Assemblée nationale, n 2855, Projet de loi relatif à la garde à vue, enregistré à la Présidence de l'Assemblée nationale le 13 octobre $2010<$ http://www.assemblee-nationale.fr/13/projets/pl2855.asp> accessed 5 October 2012. See S. Lavric, 'Présentation d'un projet de loi tendant à limiter et à encadrer les gardes à vue', Dalloz actualité, 13 septembre 2010; S. Lavric, 'Garde à vue: présentation du projet de loi en conseil des ministres', Dalloz actualité, 15 octobre 2010.

${ }^{138}$ See F. Rome, 'Garde à vue à la française: c'est la chute finale', Recueil Dalloz 2010, 2425.

139 Assemblée Nationale, Rapport fait au nom de la Commission des lois constitutionnelles, de la législation et de l'administration générale de la République, 15 décembre 2010. See also E. Allain, 'Garde à vue: fin de la première étape', Dalloz actualité, 27 janvier 2011.
} 
cassation. ${ }^{140}$ A fear of new condemnations by Strasbourg and a sense of the inevitability of the adoption of the Bill, to prevent such a development, pervaded the debates. In any case, parliament played second fiddle to the courts, in the unprecedented attack that the latter orchestrated against the inquisitorial model of custodial interrogation. Parliament's reserved attitude towards the transition to an interrogation model more consistent with adversarial principles is crystallised in the form that the Law of April $14^{\text {th }}$ has taken.

\subsection{The Law of April 14 $4^{\text {th }}$ Putting the Brakes on the Adversarial-Orientated Rights}

Recognition of the right of the suspect to 'ask that the lawyer assists him in interrogations ${ }^{141}$ is a major innovation of the Law of April $14^{\text {th }}$. Once the suspect has asked for such assistance, questioning cannot be initiated in the absence of a courtappointed lawyer or a lawyer appointed by the suspect, ${ }^{142}$ not before the expiry of a period of two hours at least. In cases where the lawyer arrives after the two hours have elapsed, the questioning has to cease, if the suspect makes such a request, to allow for a thirty-minute confidential meeting with the lawyer. ${ }^{143}$ Lawyers can now also access the report concerning the notification of rights and the questioning of the suspect. $^{144}$

In principle, the above rights should have the capacity to enhance the adversarial character of the garde à vue by creating opportunities for suspects to more actively participate in this process and to contest the officials in charge. However, these rights are subjected to a number of important exceptions, which minimize their effect on the deeply rooted inquisitorial character of the process. First of all, the Procureur de la République (the prosecutor who supervises the garde à vue) can authorize the initiation of questioning before the two-hour period has expired when the necessities of the investigation require that the suspect be immediately questioned. ${ }^{145}$ The Procureur can also decide that the presence of the lawyer in questioning should be deferred altogether, for a period of 12 hours, and can ask the Juge des libertés et de la detention (JLD) - a judge responsible for certain coercive measures taken in the course of the garde à vue - to postpone the lawyer's presence in questioning for another 12 hours. ${ }^{146}$ There must be compelling reasons for postponement, deriving from the particular circumstances of the case, either the need to collect or preserve evidence or the need to prevent an imminent attack upon other persons. In these cases, the Procureur or the JLD can also decide that the lawyer should not have access to the reports of the questioning of the suspect. ${ }^{147}$ Furthermore, the lawyer can take notes during the interview ${ }^{148}$ but cannot ask any

\footnotetext{
${ }^{140}$ See e.g. Commission des lois constitutionnelles, Compte rendu ${ }^{\circ} 25$, session ordinaire de 2010-11, 9 décembre 2010, pp 2, 4-6, 7, 8, 11, 12, 13, 15, 17; Commission des lois constitutionnelles, Compte rendu $\mathrm{n}^{\circ}$ 27, session ordinaire de 2010-11, 15 décembre 2010, pp 7-8, 29, 30; Assemblée Nationale, Compte rendu intégral, session ordinaire de 2010-11, 18 janvier 2011, pp 1, 4. <http://www.assembleenationale.fr/13/dossiers/garde_vue.asp> accessed 5 October 2012.

${ }^{141}$ Art 63-4-2 CPP.

142 Ibid.

143 Ibid.

${ }^{144}$ Art 63-4-1 CPP. The lawyer can still not access the investigation dossier though.

${ }^{145}$ Art 63-4-2 CPP.

146 Ibid.

${ }^{147}$ Ibid.

${ }^{148}$ Ibid.
} 
questions before the police have finished interviewing the suspect. ${ }^{149}$ The lawyer can be blocked from asking questions even at the end of the interview if his questions are capable of damaging the investigation. ${ }^{150}$ This means that, in reality, lawyers are restricted to providing psychological support and perhaps raising awareness of the right to silence. Granted this, it is difficult to argue that the Law of April $14^{\text {th }}$ allows suspects to obtain the whole range of services specifically associated with legal assistance as mandated by Dayanan. ${ }^{151}$

This is a fortiori the case in relation to organized crime offences, where the lawyer's intervention can be delayed for 48 hours, and in relation to terrorism and drug trafficking, where the lawyer can be excluded from the interrogation for a whole 72 hours. ${ }^{152}$ On the other hand, a positive influence of Salduz is that the above exceptional regimes can no longer be set in motion automatically on the sole basis of the type of the offence in question but rather only when there exist compelling reasons in the light of the particular circumstances of each case. ${ }^{153}$

Finally, the Law of April $14^{\text {th }}$ added an important evidentiary rule to the preliminary article (article préliminaire) of the Code of criminal procedure. It provides that "no conviction can be pronounced against a person on the sole basis of statements made without having been able to consult with a lawyer and be assisted by him'. ${ }^{154}$ At face value, this rule protects against basing a conviction on potentially unreliable confessional evidence obtained in violation of a fundamental right of the suspect. However, this is true only to the extent that there is no additional corroborating evidence. If there is, then this rule's effect is to allow the use of the confessional evidence. An amendment to this rule that would have seen the word sole removed, turning the corroboration rule into an automatic exclusionary rule, gave rise to a vivid debate in parliament, which, however, decided to retain the rule in its original form. $^{155}$

On the issue of notification of the right to silence, it suffices to note that the Law of April $14^{\text {th }}$ re-introduced the wording that was in place between 2002 and 2003; police officers have to immediately inform a suspect subjected to a garde à vue that he has the right to 'make a statement, answer the questions posed to him or remain silent'. ${ }^{156}$ The reluctance of the legislator to place the emphasis on the right to remain silent is quite obvious here; talking to the police - and risking selfincrimination - is put on an equal footing with exercising the fundamental right to remain silent.

The above provisions clearly demonstrate that the garde à vue remains ingrained with the inquisitorial logic. The rejection of adversarialism was nowhere more evident than in the decision of the Conseil Constitutionnel of 18 November 2011. Faced with a question prioritaire de constitutionnalite $e^{157}$ that challenged certain

\footnotetext{
${ }^{149}$ Art 63-4-3 CPP.

${ }^{150}$ Ibid.

${ }^{151}$ See Renucci, 'L'avocat et la garde à vue' (n 89 above) para 7.

${ }^{152}$ Art 706-88 CPP.

${ }^{153}$ Art 706-88 (6) CPP.

${ }^{154}$ Article préliminaire III.

155 J. Danet, 'La contribution à sa propre incrimination sans assistance d'un avocat ne peut avoir de force probante, pas même valeur de preuve "corroborante", Revue de science criminelle 2011, 414. The corroboration rule could lead to new convictions in Strasbourg, as Fidanci v. Turkey now demonstrates. App no 17730/07 (ECtHR, 17 January 2012). See O. Bachelet, 'Garde à vue: La Turquie à nouveau condamnée, la réforme française ménacée’, Dalloz actualité, 2 février 2012.

${ }^{156}$ Art 63-1 CPP

${ }^{157}$ See text to $\mathrm{n} 93$.
} 
aspects of the regime of police interrogation instituted with the Law of April $14^{\text {th }}$, the Court accepted that the need to reinforce defence rights did not impose that police interrogation should be conducted in a way that allows for adversarial confrontation (débat contradictoire). ${ }^{158}$ In upholding the constitutionality of various provisions limiting the lawyer's role in the garde à vue, the Court placed emphasis on the fact that the new legislative framework provided for notification of the right to silence and for lawyers to be present during the questioning of the suspect and that it prohibited basing convictions solely on confessions obtained in the absence of legal assistance. ${ }^{159}$

In brief, it appears that, even with little room for manoeuvre, the executive and legislature still mounted considerable resistance to external pressures for reform and that the judiciary, the Conseil constitutionnel in this case, accommodated such resistance.

\subsection{Why Resistance?}

For France's dogmatic attachment to a model of custodial interrogation rooted in the inquisitorial tradition, a plethora of diverse explanations can be suggested. A number of them underlie the analysis in Section II; the historic continuity of lawyers' absence from the pre-trial process coupled with an obsession with confessional evidence (culture de l'aveu), for example, or the extreme politicization of the debate on suspects' rights, especially against the background of post-9/11 security dominated political agendas. Other possible explanations may touch upon the characteristics of inquisitorial criminal procedure, for example the conception of truth discovery as 'the quintessential goal of inquisitorial justice ${ }^{160}$ or, more particularly, the emphasis on trusting the capacity of the State 'to pursue truth unprompted by partisan pressures of individual self-interest'. ${ }^{161}$ Institutional factors cannot figure less prominently in a list of possible explanations for the reluctance to endorse a more adversarial approach. Hodgson's work is a testament to this, as can be summed up in her observation that French criminal justice 'is a system which structurally and ideologically excludes the defence'. ${ }^{162}$ Perhaps efforts to explain resistance could also collapse into the simplistic thesis that the police want less intervention in their work, while lawyers want to intervene more. But since this thesis would not be idiosyncratic of France intuitively we would expect this to be true of the police and lawyers everywhere, irrespective of jurisdiction - it would fail to explain why France in particular, in contrast for example with most other European countries, has for so long failed to recognise a role for lawyers at the police station.

From this perspective, it is interesting to note that, if one concentrates on the debates in parliament, legal nationalism also emerges as a possible source of resistance of the inquisitorial ideal against the pressures for reform coming from

\footnotetext{
${ }^{158}$ H. Matsopoulou, 'Les dispositions de la loi du 14 avril 2011 sur la garde à vue déclarées conformes à la Constitution', Recueil Dalloz 2011, 3034.

${ }^{159}$ Conseil constitutionnel, Décision n ${ }^{\circ}$ 2011-191/194/195/196/197-QPC du 18 novembre 2011.

${ }^{160} \mathrm{~S}$. Thaman, 'The Two Faces of Justice in the Post-Soviet Legal Sphere: Adversarial Procedure, Jury Trial, Plea Bargaining and the Inquisitorial Legacy' in Jackson, Langer and Tillers (eds) (n 10 above) 99, 101.

${ }^{161}$ J. McEwan, 'Ritual, Fairness and Truth: The Adversarial and Inquisitorial Models of Criminal Trial' in Duff and others (eds) (n 11 above) 51, 63.

${ }_{162}$ J. Hodgson, 'The Police, the Prosecutor and the Juge d'Instruction: Judicial Supervision in France, Theory and Practice' (2001) 41 Brit J Criminol 342, 359.
} 
outside. We can take the example of Philippe Goujon MP, whose comments echo a particular discontent with Strasbourg's impact on French criminal procedure:

Everything happened as a result of the decisions of the European Court of Human Rights, which is without doubt influenced by Anglo-Saxon law. Perhaps we were wrong not to advance the principles of our Law within the international institutions. Here we are now, forced to tack on the inquisitorial procedure that applies in France mechanisms for the protection of civil liberties adapted to an adversarial procedure, which is causing great difficulties. $^{163}$

In the same vein, Michel Mercier, the Minister of Justice who brought the April $14^{\text {th }}$ legislation to parliament, reflecting on developments that he interpreted as movements towards the construction of a European criminal procedure, sounded a note of caution, insisting that the 'reform [had] to maintain a French character, since justice, which is always an expression of culture, [could] not be tacked on from outside'. ${ }^{164}$

Then again the European framework often becomes the last bastion of French resistance against reforms that find their inspiration in principles of adversarial criminal procedure. Movements away from the inquisitorial ideal are interpreted as movements towards the ECHR-inspired principle of contradictoire rather than a shift towards adversarialism, and suspects' rights are seen as engineered to facilitate informed participation rather than adversarial confrontation. ${ }^{165}$ This was a recurrent theme in the debates surrounding the 1993 and 2000 garde à vue reforms that strengthened defence rights ${ }^{166}$ and was equally present in the parliamentary debates that preceded the Law of April $14^{\text {th }} .{ }^{167}$ For a legal system heavily invested in its inquisitorially rooted pre-trial arrangements, it is arguably very difficult to admit to adversarial reforms that have the potential to unsettle - or to be seen to unsettle - such arrangements, hence the preference for the principle of contradictoire, which can be far more easily accommodated, due to being seen as a compromise of inquisitorial and adversarial criminal justice principles rather than as a pure reflection of the latter.

The above resonate well with Summers's thoughts on legal nationalism, that 'it is perhaps inevitable that criminal law and procedure, which until recently have been situated (trapped?) within the geographical and territorial confines of the nation state, should be closely identified with, and influenced by, that state' and that the indifference towards and mistrust of other criminal justice systems that this nationalism generates can hinder reform or help protect the identity of the national legal system, depending on the perspective one takes. ${ }^{168}$ This seems to be a fortiori

\footnotetext{
${ }^{163}$ Commission des lois constitutionnelles (n 126 above) 13.

${ }^{164}$ Ibid., at 22.

${ }^{165}$ For a thesis that focuses on the European construction of procedural rights as a means to enhance participation see J. Jackson, 'The Effect of Human Rights on Criminal Evidentiary Processes: Towards Convergence, Divergence or Realignment?' (2005) 68 MLR 737.

${ }^{166}$ Hodgson, French Criminal Justice (n 9 above) 28.

${ }^{167}$ Various MPs seemed hard-pressed to argue that the inquisitorial tradition did not allow France to go beyond the principle of contradictoire to endorse adversarial principles, while the Minister of Justice was careful to explain that respecting the principle of contradictoire did not mean depriving Society from the means required to defend itself. See generally Commission des lois constitutionnelles (n 126 above) 15 .

${ }^{168}$ S.J. Summers, Fair Trials: The European Criminal Procedural Tradition and the European Court of Human Rights (Oxford: Hart Publishing, 2007) 11.
} 
the case at a time of globalization, if we accept that globalization can breed nationalism. ${ }^{169}$

\section{CONCLUSION}

The contextual inquiry undertaken in this paper casts a shadow on legal cosmopolitanism's easily assumed ubiquity, especially if cosmopolitanism is defined broadly as a capacity to interact with foreign and international law, free from the parochial limitations inherent in national legal systems. Pre-April $14^{\text {th }}$ French exceptionalism in the area of custodial interrogation pinpoints a legal system that had become rigid, isolated and immune to external influences detracting from the inquisitorial model, thus exhibiting a considerable lack of cosmopolitan vision.

On the other hand, this inquiry also demonstrates that legal cosmopolitanism can be a powerful force for legal reform, as evidenced by the dramatic effect that Strasbourg jurisprudence has had upon the modern transformations of the garde $\grave{a}$ vиe. Strasbourg's influence is particularly noteworthy given the importance of current debates, on the ECtHR's growing impact on national sovereignty and national legal culture, notably in relation to criminal justice matters that are 'usually seen as very much a quintessential part of national sovereignty'. ${ }^{170}$ The ECHR's binding force and special place within the European legal landscape explain why it constitutes the most characteristic expression of Law's growing cosmopolitanism at the European level. The more crucial and troubling question then is whether Law's cosmopolitanism also manifests itself outside this context. France's exceptionalism in the area of custodial interrogation until the moment that the ECtHR took action provides the example of a country where this has evidently not been the case. ${ }^{171}$

To stay with the point, it is also intriguing to observe how the impact of external cosmopolitan influences may fluctuate depending on the institution that is at the receiving end. In relation to the Law of April $14^{\text {th }}$, the judiciary has been quick to translate ECHR jurisprudence into a true driving force for reform. Strasbourg's influence has been much less felt by the executive and the legislature, which obstructed full departure from the inquisitorial paradigm. ${ }^{172}$

The above analysis also indicates how legal cosmopolitanism goes hand in hand with local resistance. Openness to other legal cultures and receptivity of international influences can simultaneously generate resistance and insularity, often encapsulated in the idea of a defence of national legal culture. This paper provides ample evidence of this, thus resonating with globalization theories that explore the very complex, and often contradictory, ways in which the global interacts with the

\footnotetext{
${ }^{169}$ M. Kaldor, 'Nationalism and Globalisation' (2004) 10 Nations and Nationalism 161.

${ }^{170}$ D. Nelken, 'The Globalization of Crime and Criminal Justice: Prospects and Problems' (1997) 50 CLP 251. The UK offers a useful example of a legal system where the ECHR's influence upon the national criminal justice system has become a subject of controversy. See generally J.R. Spencer, 'Strasbourg and Defendants' Rights' (n 62 above) 14; J.R. Spencer, 'Hearsay Reform: The Train Hits the Buffers at Strasbourg' [2009] Cambridge Law Journal 258; N. Bratza, 'The Relationship Between the UK Courts and Strasbourg' [2011] European Human Rights Law Review 505.

${ }^{171}$ Observers in the UK will be able to draw an analogy here with recent reforms of custodial legal assistance in Scotland, which became possible only as a result of the UK Supreme Court's application of the same Strasbourg jurisprudence that led to reforms in France. See ( $\mathrm{n} 2$ above).

${ }^{172}$ To draw another analogy with the UK, in the aftermath of Salduz the High Court of Justiciary in Scotland attempted to preserve the status quo, in contrast to the UK Supreme Court that followed this case, thus opening the door to reform in Scottish criminal procedure. See F. Leverick, 'The Right to Legal Assistance During Detention’ (2011) 15 Edinburgh Law Review 353, 358.
} 
local and which accept that the global does not necessarily minimize the importance of the local. ${ }^{173}$ This paper also offers an illustration of the fact that '[g]lobalisation processes do not only favour cultural interconnectedness, they favour cultural disconnectedness as well' ${ }^{174}$ and that '[g]lobalisation involves diversity as well as uniformity, the local as well as the global'. ${ }^{175}$ From this angle, this paper agrees with David Nelken that 'the local sense of any given global initiative needs to be carefully deconstructed'. 176

The legal cosmopolitanism-local resistance duality leads to a final thought that could give birth to a further line of inquiry. In a discussion of legal cosmopolitanism, Paul Roberts underlined the 'significance of quotidian demands of local conditions 'on the ground' ', considering that their interaction with internationalism's homogenizing pressures can 'perpetuate, and indeed reinvigorate and extend the diversity and distinctiveness of national legal cultures' ${ }^{177}$ Now, in the light of the analysis of local resistance in France, we can reflect on the conditions required to facilitate and optimize this process of diversification and preservation of national legal culture that would not go against Law's growing cosmopolitanism. As is evident in this paper, local resistance can be a conservative force if it takes its roots solely in legal nationalism, tradition or the interests of members of particular legal professions, all the more so when the law resisted consists of human rights standards that are universalistic in nature and, consequently, much less affected by nation state particularities than most other domains of law. In addition, it is logical that the more power to initiate legal reform is given to international and transnational law institutions, the more the likelihood for resistance increases. Legal reform in such cases appears in the eyes of the nation state as being 'imposed' from above, an attack on national sovereignty, hence the increased likelihood for resistance as opposed to a scenario where the need for reform would have been recognized from inside.

In view of the above, for the interaction between cosmopolitanism and resistance to produce the positive effect described by Roberts, it is instructive to ask whether legal cosmopolitanism can go beyond mere domestication of international law to find accommodation within the legal system itself. Put another way, we need to consider what needs to be done for legal systems to start using the full spectrum of the institutional sources of law; what needs to be done so that, in addition to looking upwards to public international law - as French courts have done in this case, with admirable results -, legal systems also start looking outwards and sideways to foreign legal systems and the possibilities of engaging in a true dialogue with them. ${ }^{178}$

A renewed emphasis on comparative law and comparative legal studies, as a means to generate genuine interest from within national legal systems for the solutions adopted in foreign legal cultures and international legal orders, may then have a lot to commend it as the appropriate way forward towards truly cosmopolitan legal systems, considering in particular comparative law's dual function; its ability to contribute to integration, by making it possible to bypass divergence through

\footnotetext{
${ }^{173}$ See W. Twining, Globalisation \& Legal Theory (CUP 2000) 5.

${ }^{174}$ Kaldor (n 169 above) 166.

${ }^{175}$ Ibid.

${ }^{176}$ D. Nelken, Comparative Criminal Justice (Sage 2010) 78.

177 'Faces of Justice Adrift?' (n 13 above) 328.

${ }^{178}$ See Roberts and Zuckerman (n 124 above) 703.
} 
synthesis and hybridization, as well as its ability to lead to resistance ${ }^{179}$ by explaining the differences and reinforcing national solutions. ${ }^{180}$

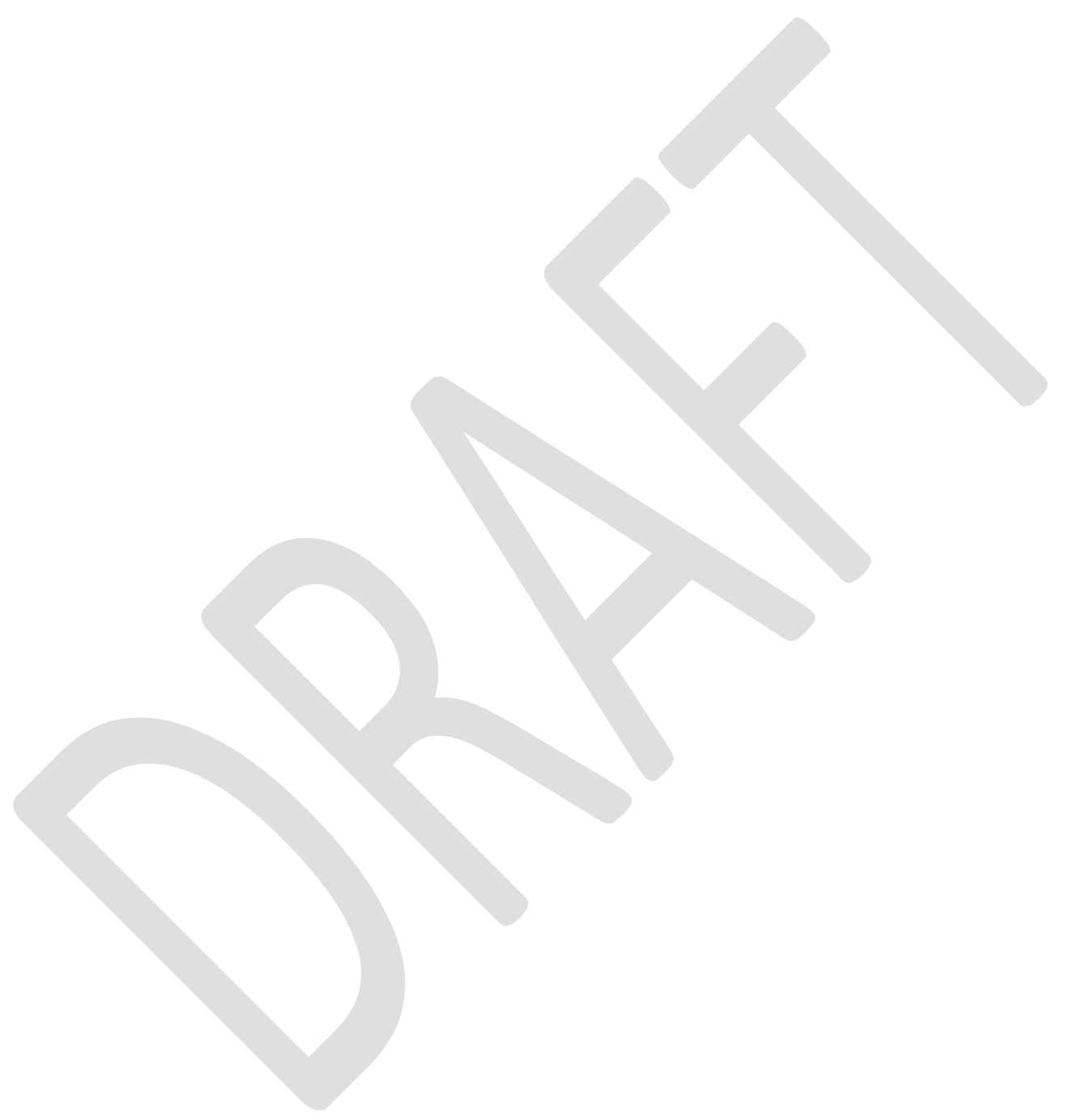

${ }^{179}$ M. Delmas-Marty, Les forces imaginantes du droit: Le relatif et l'universel (n 119 above) 15.

${ }^{180}$ Canivet, 'The Practice of Comparative Law by the Supreme Courts' (n 19 above) 325. 